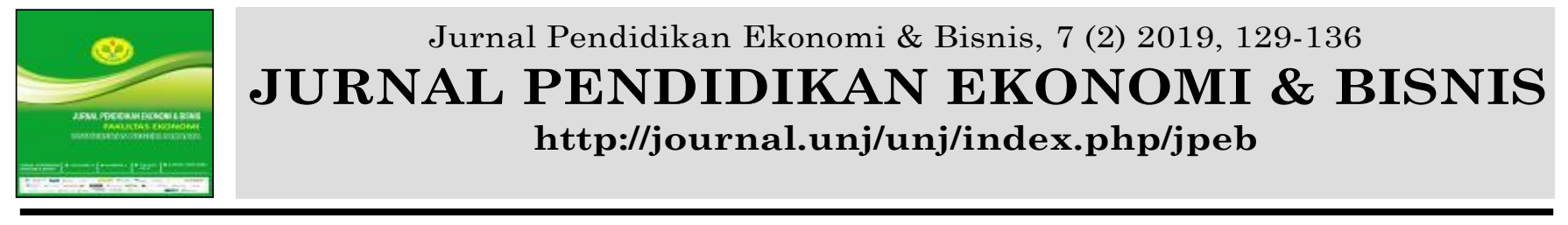

\title{
Does the Stocklab Game Increase Students' Understanding on Stock Markets?
}

Muhammad Abdul Ghofur ${ }^{1}$, Nuzuliya Rohma Qurrota Ag'yun²

${ }^{1}$ Universitas Negeri Surabaya, Indonesia

${ }^{2}$ Universitas Negeri Surabaya, Indonesia

\begin{tabular}{l}
\hline Article Info \\
\hline Article history: \\
Received: 19 July 2019; \\
Accepted: 22 September 2019 ; \\
Published: 30 October 2019.
\end{tabular}

Keywords:

Student Understanding;

Stocklab Games; Stock

Markets.

\begin{abstract}
This study aimed to analyze the use of stocklab game to improve students' understanding of the stock market. This research was a quasi-experimental study with a nonequivalent control group design. The object of this study were students of class X IPS in MAN Surabaya. Class X IPS 2 was determined as the experimental class while class X IPS 3 as the control class. Both classes were given the same treatment using cooperative learning methods make a match type and numbered head together, however in the experimental class, games were given in the form of stocklab games. The analysis technique used to test the research hypothesis was one way ANOVA. Hypothesis tested by comparing the pretest and post-test scores in both classes. Based on the analysis results, it was known that there were differences in students' understanding of the control class and the experimental class, where the understanding of the experimental class students tend to be better than students in control class. In addition, students also tend to understand more stock market terms.
\end{abstract}

\section{Abstrak}

Penelitian ini bertujuan untuk menganalisis penggunaan game stocklab untuk meningkatkan pemahaman siswa tentang materi pasar modal. Penelitian ini merupakan penelitian kuasi eksperimen dengan desain nonequivalent control group. Obyek penelitian ini adalah siswa kelas X IPS MAN Surabaya. Kelas X IPS 2 ditentukan sebagai kelas eksperimen, dan kelas X IPS 3 sebagai kelas kontrol. Kedua kelas tersebut di beri perlakuan yang sama menggunakan metode pembelajaran cooperative learning tipe make a match dan numbered head together, namun pada kelas eksperimen diberikan game berupa game stocklab. Teknik analisis yang digunakan untuk menguji hipotesis penelitian ini adalah one way anova. Uji hipotesis dengan membandingkan nilai pre-test dan post-test masing-masing kelas serta nilai post-tes pada kedua kelas. Berdasarkan hasil analisis diketahui adanya perbedaan pemahaman siswa di kelas kontrol dan kelas eksperimen, dimana pemahaman siswa kelas eksperimen cenderung lebih baik. Siswa juga cenderung lebih banyak memahami istilah-istilah pasar modal

\section{How to Cite:}

Abdul Ghofur, M., \& Nuzuliya Rohma Qurrota Agyun. (2019. Does the Stocklab Game Increase Students' Understanding on Stock Markets? Jurnal Pendidikan Ekonomi \& Bisnis, 7(2), 129-136. https://doi.org/10.21009/JPEB.007.2.4

* Corresponding Author.

muhammadghofur@unesa.ac.id. Muhammad Abdul Ghofur 


\section{INTRODUCTION}

Learning output is closely related to student understanding. Students are said to have learned something when they can understand or interpret the meaning of what they have learned. According to Winkel (1999, p. 53), learning is a mental/psychological activity that takes place in active interaction with the environment that can produce changes in knowledge, understanding, skill, and attitude. These changes are relatively constant and trace. These changes can be in the form of new result or improvement to the result that has been obtained previously. To see the extent of students' understanding of learning material, we can examine it using indicators of understanding, namely translating, interpreting, and extrapolating. Translating is the ability to translate words into other languages or make abstract concepts become symbolic that can be understood by others. Interpreting is the interpretation ability to recognize, understand, and connect the prior knowledge with new knowledge. Moreover, extrapolating is the highest comprehension ability where a person can see things that are implied from one thing and make prediction about a case, problem, and so forth (Kuswana, 2012, pp. 43-49).

This understanding will determine one's attitude and decision making. In economics, every individual has a rational standart for making decision. Weak understanding will determine the accuracy of attitude and decision making. One of the big problems in Indonesia is low public financial literacy, especially in the stock market sector. Based on a national survey conducted by the Otoritas Jasa Keuangan (OJK) in 2016, our society's stock market literacy rate was 4.4 percent, while the stock market sector's financial inclusion index was still far below that, which was 1.3 percent (Otoritas Jasa Keuangan, 2017). Economic learning in senior high schools (SMA) has become an essential element in efforts to increase financial literacy, especially in the stock market sector. According to Kemu (2017), it turns out that the low public literacy about the stock market is caused by the wrong assumption of investment in the stock market, low technical knowledge about the stock market, and fear of loss.

Effort to increase student understanding is by choosing the right media. Each learning media has advantages and disadvantages that must be identified by the teacher so that it can be adapted to the students' need, learning objectives, the availability of supporting facilities, rules, and so on. However, the most important thing is the ability of the media to support the learning process of its features. Instruction using simulation games can be one of the reliable solutions. Simulation game allows students to experience situations like the real world. Students can learn as if they were investors in a stock market using a type of management simulation game. They can plan investment objectives, when they buy or sell the shares.

The game has become a part of every student's life. They are the native digital generation who are used to play various types of games, including simulation game. Games can be optimized for learning. By playing games, students can be encouraged to be able to process visual information faster, more quickly to identify a thing or problem that is happening (Tapscott, 2009, p. 105). Schell (2008, p. 101) also states that teenagers 13-18 years old are very interested in trying new things, one of which is playing games to find new experiences.

Simulation games are used in classroom learning because of the high level of student participation and involvement, making the learning process more enjoyable, and especially being able to replicate real-life scenarios. The feedback that can occur in real-time during simulations can improve students' motivation to find better solutions to the problems presented in the game to improve knowledge faster. Research conducted by Fauziah, Abdulkarim, \& Wiyanarti (2017) shows that media games can improve student understanding. Also, research by Vlachopoulos \& Makri (2017) prove that it has positive impact on the achievement of learning goals, can motivate and engage students more, and provide opportunities for students to actively experience, practice, interact, and reflect collaboratively, game-based, and centered to students.

Students consider the use of simulation games in learning to be very useful and provide valuable knowledge and skills (Vos \& Brennan, 2010). Games, in which there are negotiating mechanisms, also proven to be able to improve learning outcomes (Chen, Lu, \& Chou, 2019). Realtime feedback provided during the simulation game also has a positive impact on students' 
cognitive learning outcomes (Nkhoma et al., 2014).

In this study, researchers used a simulation game, "Stocklab Game," on stock market material. Stock market material is one of learning material that is considered difficult by students, and it is impossible to provide direct experience for students if it is not through simulation. Students also have not been able to directly make transactions in the stock market because of the age insufficient. The game development was initiated by OJK and IDX, which in cooperation with experienced game developer Ryan Filbert. The game was developed to make it easier for the public to understand the stock market. Students who are just learning about the stock market will be able to understand the stock market using this game easier. However, students should already have a basic knowledge of the stock market.

The Stocklab game has several components and phases of play. These components are stock sector cards, mutual fund cards, business cards, action cards, split tokens, money coins, debit cards, manual cards, and order cards. The game phases consist of the bidding phase, the action phase, the selling phase, and the economic phase. This game can be done in groups of 3-5 people. In the stocklab game there are four phases namely the bidding phase where players open their action cards, the action phase where each player takes a card to increase their shares or use the effects on the card, the selling phase where players can sell their shares, and the economic phase where each sector can be seen going up or the decline in their shares so they can know the loss of profit.

Stocklab games have the goal of educating players about investing in the stock market, having conflicts in the game that can trigger students to develop the strategies to resolve conflicts in the game so that students indirectly have to understand the concepts of the stock market. Each player has almost the same chance to become a winner, so students can compete with each other so they can win in the game. Competitions conducted by students in playing games can determine their learning performance (Zumbach, Rammerstorfer, \& Deibl, 2020). Stocklab games are the kind of simulation games and serious games. In classroom, this game can be used as supplemental or replacement learning. Games used in a supplemental way means that the game can be played in extra class. If the games used as a replacement means that the game is played on a indoor activity without extend the lessson hours.

\section{METHOD}

This research was an experimental study to obtain empirical evidence about the application of stocklab games in learning. The experimental design used was Quasi-Experimental Design because the members of the control group and the experimental group were not randomly determined. Overall, population taken from social major students' (IPS) of MAN Surabaya X grade in the 2018-2019 school year which consisted of 3 classes of 107 students. The complete data are presented in table 1. Class X IPS 2 were chosen as the experimental class and class X IPS 3 as the control class.

Table 1.

Population class X IPS

\begin{tabular}{ll}
\hline Class X & Total \\
\hline X IPS 1 & 36 Students \\
X IPS 2 & 35 Students \\
X IPS 3 & 36 Students \\
\hline Total & 107 Students \\
\hline
\end{tabular}

The research instrument was a written test which conducted by researchers in the form of pretest and posttest with multiple-choice questionnaires. Pretest used to measure student understanding before given treatment, while posttest aimed to measure student understanding after given treatment. The research instrument consisted of 40 items and eight indicators. Each indicator contains several items with different amounts. The research instrument will be tested 
using item analysis to find out which questions were appropriate to be used as research instruments to measure students' understanding of the stock market mechanism.

This research used quantitative data analysis. Before being used as a test tool, the research instruments were analyzed using item analysis, namely the difficulty level test, test of distinguishing questions, the validity test, and the reliability. Before being used for hypothesis testing, the test results were seen for their normality and homogeneity first. The normality test used Kolmogorov Smirnov test and Levene's Test for Equality of Variance to examine the homogenity. Hypothesis examined by the Anova test or the F test. In this study, one-way Anova analysis was used because there was only one factor, namely the use of stocklab games. To examine the effectiveness of the treatments used the N-Gain Score test.

\section{RESULTS AND DISCUSSION}

Researchers prepare research instruments in the form of as many as 40 items. After analyzing the item, the researcher only used 20 questions as a research instrument to measure the level of student understanding. The results of the item analysis are presented in table 2, where only 20 subjects were declared valid. In the control class and experimental class, the researchers gave the same learning model treatment at two meetings. However, at the last meeting in the experimental class, learning was carried out using the Stocklab game as a replacement (Twigg, 2003).

Table 2.

Result of Test Items Analysis

\begin{tabular}{lllllll}
\hline \multicolumn{2}{l}{$\begin{array}{l}\text { Item Difficulty } \\
\text { Level }\end{array}$} & \multicolumn{2}{l}{ Power Difference Test } & \multicolumn{2}{l}{ Instrument Validity } & \multicolumn{2}{l}{$\begin{array}{l}\text { Instrument } \\
\text { Reliability }\end{array}$} \\
\hline Criteria & Amount & Criteria & Amount & Criteria & Amount & Value \\
\hline Difficult & 7 & Bad & 15 & Valid & 20 & 0.822 \\
Moderate & 26 & Moderate & 21 & Invalid & 20 & Reliable \\
Easy & 7 & Good & 3 & & & \\
& & Very Good & 0 & & & \\
& & Everything is & 1 & & & \\
& & & & & & \\
& & & & & & \\
& &
\end{tabular}

Tests for students' understanding of the stock market in both classes were conducted before instruction (pre-test) and after instruction (post-test). The results of the pre-test control class turned out to have an average value higher than the experimental class that is 51.25 versus 35.44 . The average difference between the pre-test results of the control class and the experimental class was 15.81 . The average post-test results in the control class were 56.25 in the experimental class. The average reached 69. A summary of the pre-test and post-test results are presented in Table 3.

Table 3.

Pre-test and post-test Result

\begin{tabular}{llll}
\hline Class & $\begin{array}{l}\text { Pre-test } \\
\text { mean } \\
\text { results }\end{array}$ & $\begin{array}{l}\text { Post-test } \\
\text { mean } \\
\text { results }\end{array}$ & $\begin{array}{l}\text { Percentage of } \\
\text { increase }\end{array}$ \\
\hline Control & 51.25 & 56.25 & $9.75 \%$ \\
Experiment & 35.44 & 69 & $94.69 \%$ \\
\hline
\end{tabular}

The percentage of pre-test dan post-test of experiment class increase sharply compared to control class. The results of the control class pre-test, which have an average value higher than the experimental class. However, the post-test results showed a very significant difference where the mean score of the post-test in the experimental class turned higher than the control class.

After conducting traditional comparisons, researchers re-tested using statistical analysis through a one-way ANOVA analysis. ANOVA analysis results are the first to see whether or not 
there are differences in student grades in the control class after the pre-test and post-test. The results of this test are summarized in Table 4.

Table 4.

Anova Test Results Pre Test \& Post Test Control Class

\begin{tabular}{|c|c|c|c|c|c|c|}
\hline & & $\begin{array}{l}\text { Sum of } \\
\text { Squares }\end{array}$ & $\mathrm{df}$ & $\begin{array}{l}\text { Mean } \\
\text { Square }\end{array}$ & $\mathrm{F}$ & Sig. \\
\hline \multirow{2}{*}{\multicolumn{2}{|c|}{$\begin{array}{l}\text { Between } \\
\text { Groups } \\
\text { Within } \\
\text { Groups }\end{array}$}} & 450.000 & 1 & 450.000 & \multirow[t]{2}{*}{2.040} & \multirow[t]{2}{*}{0.158} \\
\hline & & 15437.500 & 70 & 220.536 & & \\
\hline & $\mathrm{N}$ & & Mean & \multicolumn{2}{|c|}{ Minimun } & Maximum \\
\hline $\begin{array}{l}\text { Pre } \\
\text { Test }\end{array}$ & 36 & & 51.2500 & \multicolumn{2}{|c|}{20.00} & 80.00 \\
\hline $\begin{array}{l}\text { Post } \\
\text { Test }\end{array}$ & 36 & & 56.2500 & \multicolumn{2}{|c|}{15.00} & 80.00 \\
\hline
\end{tabular}

There was no significant increase in learning outcomes in the control class. The significance value is 0.158 , which is higher than 0.05 (a). Although there is a difference in the average amount of students by 51.25 , which rises to 56.25 , the difference is not significant.

Table 5.

Anova Test Results Pre Test \& Post Test Experiment Class

\begin{tabular}{llllll}
\hline & $\begin{array}{l}\text { Sum of } \\
\text { Squares }\end{array}$ & $\mathrm{df}$ & $\begin{array}{l}\text { Mean } \\
\text { Square }\end{array}$ & $\mathrm{F}$ & Sig. \\
\hline $\begin{array}{l}\text { Between } \\
\text { Groups } \\
\text { Within } \\
\text { Groups }\end{array}$ & 19891.429 & 1 & 19891.429 & 153.060 & 0.000 \\
\hline \multicolumn{1}{c}{$\mathrm{N}$} & 8837.143 & 68 & 129,958 & & \\
\hline $\begin{array}{l}\text { Pre } 35 \\
\text { Test }\end{array}$ & & Mean & Minimun & Maximum \\
$\begin{array}{l}\text { Post } 35 \\
\text { Test }\end{array}$ & & 35.2857 & 15.00 & 65.00 \\
\hline
\end{tabular}

Table 5 explains the results of the second ANOVA analysis, which is to look at the ANOVA test in the pre-test and post-test experimental classes, which revealed a significant difference. This significant value is proven by the probability value of 0,000 , which is smaller than 0.05 ( $\alpha$ ). The mean score of the experimental class pre-test was 35.28, and the post-test value was 67.28. From this value, it can be seen that there is a very high increase.

This comparison is not wholly objective, considering that the two classes tend to be unequal when viewed by the mean pre-test scores. As a comparison of fair comparison efforts, a variant test was performed on the results of the control class and experimental class post-test. In table 6 , a summary of the results of this comparison test is presented, and the result is a real difference between the post-test scores of the control class and the experimental class, where the experimental class is proven to be better than the control class. 
Table 6.

Anova Test Results Post Test of Control and Experiment Class

\begin{tabular}{llllll}
\hline & $\begin{array}{l}\text { Sum of } \\
\text { Squares }\end{array}$ & df & $\begin{array}{l}\text { Mean } \\
\text { Square }\end{array}$ & F & Sig. \\
\hline $\begin{array}{l}\text { Between } \\
\begin{array}{l}\text { Groups } \\
\text { Within }\end{array}\end{array}$ & 2161.290 & 1 & 2161.290 & 9.2997 & 0.0032 \\
Groups & 16035,893 & 69 & 232,404 & & \\
\hline & $\mathrm{N}$ & Mean & Minimun & Maximum \\
\hline Control & 36 & 56.25 & 15.00 & 80.00 \\
Experiment & 35 & 67.286 & 30.00 & 85.00 \\
\hline
\end{tabular}

Furthermore, to emphasize the difference test, the N-Gain Score difference test was performed. This test summary is presented in table 7 . The test results that there are significant differences in the effectiveness of learning between the control class and the experimental class.

Table 7.

Anova N-Gain Score Test Results

\begin{tabular}{llllll}
\hline & $\begin{array}{l}\text { Sum of } \\
\text { Squares }\end{array}$ & $\mathrm{df}$ & $\begin{array}{l}\text { Mean } \\
\text { Square }\end{array}$ & $\mathrm{F}$ & Sig. \\
\hline $\begin{array}{l}\text { Between } \\
\text { Groups }\end{array}$ & 48347.649 & 1 & 48347.649 & 30.500 & 0.000 \\
$\begin{array}{l}\text { Within } \\
\text { Groups }\end{array}$ & 109377.250 & 69 & 1585.178 & & \\
\hline & & & & & \\
\hline & $\mathrm{N}$ & Mean & Minimun & Maximum \\
Control & 36 & -1.1480 & -140.00 & 63.64 \\
Experiment & 35 & 51.0473 & 0.00 & 78.57 \\
\hline
\end{tabular}

Students/players felt the benefit of games include; can create a strong learning motivation in students during learning, make students like an eye, stimulate fun and excitement in learning, and useful as a medium for repetition or training for students. In playing games, students will repeat each phase and terminology so that students will unconsciously repeat the same material, and it is suitable for students because repetition has proven to be very useful in maintaining students' understanding and memories while triggering the growth of other related understandings (Ghofur, 2019).

Another game effect is to stimulate students 'intellectual skills while playing through problems or conflicts encountered, fostering students' metacognitive development because games contribute to construct and develop new learning strategies. Research by Chen et al. (2019) has proven this, where students are required to have negotiation skills and display the right attitude when facing investment problems. Theoretically, Stocklab Game can be relied upon to improve student understanding, because student understanding is obtained by the results of constructs from experiences that have occurred. When students play the game, the senses of students are also stimulated to work more effectively and always focus, especially in a competitive situation so that learning performance increases (Zumbach et al., 2020). This view of constructivism is based on Confucius' statement in Amri (2015, p. 53), including 1) What I heard, I forgot. 2) What I see, I remember. 3) What I do, I understand. In the Edgar Dale Cone also explained that learning with simulated media can improve student memory by as much as $90 \%$ of the material being studied. This is because students get real experience related to the content of learning material (Sani, 2014, p. 61).

According to the three indicators of understanding, students' understanding level can be measured through the results of tests that have been done. In the presentation of the pre-test and 
post-test results above, it has been explained that there was an increase in learning outcomes, however the growth was higher in the experimental class than the control class. Related to the meaning of each indicator, students have fulfilled all of three indicators. Furthermore, examining students wheter understand or not about learning material is can be done with several ways, such as: conduct the interviews and observe the students activeness when they learn in class, or we can see the results of the assignments that have been given.

In the first indicator, the translating stage, MAN Surabaya students already know and familiar with the terms of the stock market along with other terms contained in the stock market lesson they learn. Then the second indicator is interpretation. MAN Surabaya students have studied and understood stock market materials such as: the functions, roles, benefits, and forms of stock market products. Therefore, students not only know the kind of stock market products but also recognized the benefits and uses.

The last indicator, extrapolating, also shows results that are not much different. Extrapolating is means that students are able to solve problem, make prediction, conclude what they have been learned using their language. MAN Surabaya students have been able to explain stock market material use their language and make conclusion related to the content they have learned. Based on the researchers' observation during the research process reveal some benefits of stocklab game such as: students can memorize the terms in the stock market easier because in the components and phases of the game a lot of words that are commonly used in the stock market, students can understand how to invest and make transactions in the stock market in the stock market because each phase of the game is the stages of real trades in the stock market. Theoretically, when information is frequently recalled, the data will survive in short-term memory and have a higher chance of entering one's long-term memory.

In addition to improve the ability to remember stock market terms, the application of this game will hone its critical thinking skills to develop strategies to win the game. When they feel the excitement of being right in making a decision, then later getting the results of that decision, students begin to feel the soul of an investor. Patience in making decisions will also be tested, mainly if the judgment contains risks, then he will be forced to learn from mistakes.

The game's application in learning certainly has some weaknesses. According to the researchers' observations, the use of this game requires quite a lot of time, and it takes at least 60 minutes exclude preparation. An initial understanding of the stock market is also a critical requirement that every player must-have. When playing the stocklab game, someone who is familiar with the game is needed to be a game guide and banker, because there are many terms and rules in the stocklab game. If no one understands this game, then the game cannot run properly.

\section{CONCLUSIONS AND SUGGESTION}

Based on the results of the analysis and discussion, it can be concluded that there is a real contribution in the application of stocklab games to improve students' understanding of stock market material in class X IPS MAN Surabaya. The learning outcomes of the experimental class tend to be better than the control class. Using this game is giving some benefits because students are more familiar with the terms in the stock market, able to interpret stock market content, able to explain stock market material using their own language, and able to make conclusions from the learning material. This game is highly recommended for use in stock market learning at the high school level because it offers hands-on experience and direct action by students, but it is necessary to arrange further implementation schedules more efficient and in accordance of teacher assistance. 


\section{REFERENCES}

Amri, S. (2015). Implementasi Pembelajaran Aktif dalam Kurikulum 2013 (E. Ersaela, Ed.). Jakarta.

Chen, Z. H., Lu, H. De, \& Chou, C. Y. (2019). Using game-based negotiation mechanism to enhance students' goal setting and regulation. Computers and Education, 129, 71-81. https://doi.org/10.1016/j.compedu.2018.10.011

Fauziah, I., Abdulkarim, A., \& Wiyanarti, E. (2017). The Effectiveness of The Use of Board Game Towards The Comprehension of The Concept of Sosial Science Subjects. International Journal Pedagogy of Social Studies, 2(2), 15-18.

Ghofur, M. A. (2019). Pentingnya Gim Edukasi dalam Pembelajaran Modern. Retrieved from 18 Juli 2019 website: https://maglearning.wordpress.com/2019/07/18/pentingnyagim-edukasi-dalam-pembelajaran-modern/

Kemu, S. Z. (2017). Literasi Pasar Modal Masyarakat Indonesia. Kajian, 21(2), 161-175. https://doi.org/10.22212/KAJIAN.V21I2.773

Kuswana, W. S. (2012). Taksonomi Kognitif. Bandung: PT Remaja Rosdakarya.

Nkhoma, M., Calbeto, J., Sriratanaviriyakul, N., Muang, T., Tran, Q. H., \& Cao, T. K. (2014). Towards an understanding of real-time continuous feedback from simulation games. Interactive Technology and Smart Education, 11(1), 45-62. https://doi.org/10.1108/ITSE-03-2013-0005

Otoritas Jasa Keuangan. (2017). Survei Nasional Literasi dan Inklusi Keuangan 2016. Jakarta.

Sani, R. A. (2014). Inovasi Pembelajaran. Jakarta: Bumi Aksara.

Schell, J. (2008). The Art of Game Design. https://doi.org/10.1103/PhysRevD.38.3763

Tapscott, D. (2009). Grown Up Digital: How the Net Generation is Changing Your World. New York: McGraw-Hill Education. https://doi.org/10.2501/S0265048709090490

Twigg, C. A. (2003). Improving learning and reducing costs: new models for online learning. Educause Review, 38(5), 28-38. https://doi.org/10.1016/j.ygeno.2009.08.012

Vlachopoulos, D., \& Makri, A. (2017). The effect of games and simulations on higher education : a systematic literature review. International Journal of Educational Technology in Higher Education, 14(22), 1-33. https://doi.org/10.1186/s41239-017-00621

Vos, L., \& Brennan, R. (2010). Marketing simulation games: Student and lecturer perspectives. Marketing Intelligence and Planning, 28(7), 882-897. https://doi.org/10.1108/02634501011086472

Winkel, W. . (1999). Psikologi Pengajaran. Jakarta: Grasindo.

Zumbach, J., Rammerstorfer, L., \& Deibl, I. (2020). Cognitive and metacognitive support in learning with a serious game about demographic change. Computers in Human Behavior, 103, 120-129. https://doi.org/10.1016/j.chb.2019.09.026 